RESEARCH ARTICLE

\title{
JUDGMENT CONSIDERATIONS REGARDING DECISIONS ABOUT CHILD SEX ABUSE CRIME CONDUCTED BY MILITARY MEMBER
}

\author{
Novi Anggraini Putri ${ }^{1_{凶}}$ \\ ${ }^{1}$ Postgraduate Program, Master of Laws, Universitas Negeri Semarang, Indonesia \\ $\triangle$ novianggrainiputril7@gmail.com
}

\section{CITED AS}

Putri, N.A. (2020). Judgment Considerations Regarding Decisions about Child Sex Abuse Crime Conducted by Military Member. Journal of Law and Legal Reform, 1(2), 241258. DOI: https://doi.org/10.15294/jllr.vli2.35421

\begin{abstract}
TNI and Children are the two parties that are protected by special laws and regulations. Members of the TNI are committed and submit to military legislation. Apparatus who committed crimes have to follow the military's criminal law and military court. Mean while, children as the victims of criminal acts have the rights that are legally protected in the legislation on child protection. The problems on this research are (1) How is Implementation of Act No. 35 of 2014 about Child Protection against child sex abuse committed by TNI in Judicial Process at Military Court II-10 Semarang? (2) How does the judge's consideration about the Criminal adjudication to the suspect of the child sex abuse committed by TNI (Case Study of Military Court II-10 Semarang's Verdict No. 62-K/PM.II-10/AD/IX/2016)? This study uses a qualitative method located in Indonesia with a Verdict as the object of research. The data collection techniques using document and literature study. The result of research, 1) Implementation of Act No. 35 of 2014 About Child Protection in Judicial Process at Military Court II-10 Semarang, such as (1) Arresting the defendant (2) Giving the child as a victim an opportunity to speak up some testimony (3) The result of Visum et Repertum as a Health service (4) Giving detention and forfeit to defendant along with dismissal from military service 2) Judge's consideration of the Criminal adjudication of perpetrators of the Child Sex Crimes committed by TNI (1) Juridical considerations, i.e : Indictment, testimony of witnesses and defendants, expert's testimony, evidence and other articles in the Child Protection Law (2) Non-Juridical Considerations are mitigating and aggravating factors. The conclusion of this research is that the Implementation of Act no. 35 of 2014 has not been fully implemented in the judicial process in Military Court II-10 Semarang, the child's identity in the previous verdict is not disguised. Suggestion from this study is the punishment of the defendant should refer to Act no. 35 of 2014 on Child Protection and after the judicial process the parties including law enforcement should provide protection for the future of the child as a victim.
\end{abstract}

Keywords: Sex Abuse, Children, Military Judicial Process 


\section{TABLE OF CONTENTS}

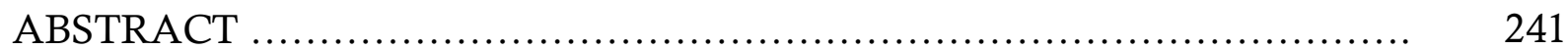

TABLE OF CONTENTS ................................................... 242

INTRODUCTION ....................................................... 242

METHOD .............................................................. 244

CHILD PROTECTION FROM SEXUAL ABUSE ............................ 244

I. IMPLEMENTATION OF LAW NUMBER 35 OF 2014 REGARDING THE PROTECTION OF CHILDREN AGAINST THE CRIME OF SEXUAL INTERCOURSE AGAINST CHILDREN

A. Implementation of Law Number 35 of 2014 Regarding the Protection of Children Against the Crime of Sexual Intercourse against Children Committed by Members of The TNI in The Judicial Process at the Military Court II-10 Semarang .........................................

II. ANALYZING JUDGES' CONSIDERATIONS REGARDING THE CONVICTION OF THE PERPETRATORS OF THE CRIME OF SEXUAL INTERCOURSE WITH CHILDREN COMMITTED BY MEMBERS OF THE TNI (CASE STUDY OF THE DECISION OF MILITARY COURT II-10 SEMARANG NUMBER 62-K/PM.II10/AD/IX/2016)

A. Juridical Considerations .......................................... 248

B. Non-Juridical Considerations ....................................... 252

CONCLUSION .......................................................... 253

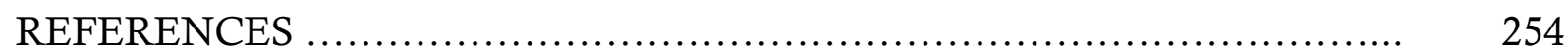

\section{INTRODUCTION}

People who choose problems, problems come and go without end. Humans are entwined with problems that they cause themselves, this problem makes humans as a lost direction and purpose.(Woolf et al., 2019) Humans who have desires that are fulfilled, because the desires and desires that win over lust and excessive desire then fails to develop. This causes more and various kinds of problems it faces (Wood et al., 2019).

Niebuhr suggested, that in humans there will always be life (the will to live) which is a source of potential for creativity. However, in humans, there is also always a desire to rule (the will to rule) which is the source of various human destructive actions. It is said to be destructive, because this desire for power never knows the final word, never knows the boundary, never knows the word enough (Wismayanti, O'Leary, Tilbury, \& Tjoe, 2019).

Niebuhr's criticism in the book Abdul Wahid and Muhammad Irfan, was shown to humans who failed to fulfill their humanitarian duties, dragged on the insistence of interests, greed, lust, and ambition that were difficult to control or 
directed into potential to support the implementation of goodness for fellow human beings, nation and state.(Winstanley \& Stover, 2019) Humans sometimes fail to prevent themselves from deviating and evil because of economic interests, biological demands, competition for prestige, status and self-esteem. Even though the crime he committed was a form of denial of human norms and values (Wang, Wu, Chang, \& Lu, 2019).

Women are being subjected to castration and abuse of their rights. Women are powerless in the face of a justified individual, cultural and structural barbarities. The values of decency that should be maintained purity are being torn apart and tainted by animalistic instincts that are given a place to act as superpowers (Vriesman et al., 2019). Violence of harassment and sexual exploitation does not only affect adult women, but also women who are classified as minors (children). This sexual crime does not only take place in a corporate environment, office space or in certain places that provide opportunities for people of different types to communicate with one another but can also occur in the family environment. The thing that is of considerable concern is the tendency for sexual violence to spread not only to adult women but also to underage children (Komori et al., 2019).

Child criminal law can be interpreted as a set of legal regulations, which regulate children who commit a crime (Juvenile Delinquency) and children as victims of crime or crime (Verduyckt, Rhéault, Remacle, \& Morsomme, 2018). The crime of rape or sexual intercourse against a child, including into one of the legal issues that are very important to be studied in-depth. As is known, the crime of rape is an act that violates social norms namely politeness, religion, and decency, especially if the raped is a child who physically does not have sexual attraction as in adolescent and adult women.(Saito et al., 2019) In contrast to adultery committed by an adult, it is natural that the offender must be responsible because both his conscience and common sense are able to receive punishment in return for his actions. However, if the offender is a minor, they have never carefully thought about the legal consequences of his actions (Reed, Kennedy, Decker, \& Cimino, 2019).

Yet as we know that children are the nation's assets that must be protected and protected from all forms of violence and crime that can endanger the safety of children. Especially if the person who commits such a heinous act is a member of the military. As a citizen, a TNI soldier is required to submit to all provisions both private and public law, especially in criminal offenses which are also included in the realm of public law.(Ramiro et al., 2019) Violations of the provisions in the Criminal Code such as theft, embezzlement, and in particular on acts of violating decency such as adultery make a TNI soldier liable for accountability for that criminal act. The obligation of a TNI Soldier is an act of a TNI soldier to comply with awareness, obedience, and obedience to the norms and ethics that apply in society as outlined in the legislation (Klifto et al., 2019).

This paper examines and analyzes two main point: first, how is the Implementation of Law Number 35 Year 2014 Regarding the Protection of Children against the crime of sexual intercourse against children committed by members of the TNI in the Judicial Process at the Military Court II-10 Semarang?, and second, how is 
the Judge's consideration regarding the conviction of the perpetrators of the crime of sexual intercourse with children committed by members of the TNI (Case Study of the Decision of Military Court II-10 Semarang Number 62-/PM.II-10/AD/IX/2016)?

\section{METHOD}

This type of research is normative juridical research, which is library research that is research on secondary data. In this study, the authors use a case approach (Case Approach) case approach in normative legal research aims to study the norms or legal norms carried out in legal practice, the case approach is carried out by reviewing cases related to research material that has been decided by a court that has permanent legal force (Panlilio, Miyamoto, Font, \& Schreier, 2019). The data source used in writing this law is a secondary data source. Secondary data sources consist of primary data and secondary data, primary data is data obtained through interviews (interviews) directly with the parties concerned, through research. While secondary data is data obtained through literature relevant to the problem understudies such as books, legislation, and other documents directly related to the issues discussed in this study. The edited data is then analyzed qualitatively, namely data analysis in the form of sentences and descriptions used to analyze data that cannot be measured with numbers. Qualitative data analysis is done by testing the data with concepts, theories and answers obtained from respondents, wherewith this method it is expected that clear data will be obtained on the subject matter.

\section{CHILD PROTECTION FROM SEXUAL ABUSE I. IMPLEMENTATION OF LAW NUMBER 35 OF 2014 REGARDING THE PROTECTION OF CHILDREN AGAINST THE CRIME OF SEXUAL INTERCOURSE AGAINST CHILDREN}
A. Implementation of Law Number 35 of 2014 Regarding the Protection of Children Against the Crime of Sexual Intercourse against Children Committed by Members of The TNI in The Judicial Process at the Military Court II-10 Semarang

In this study, the author only examines the decision in view of Law No. 35 of 2014 concerning Child Protection, the law has included the rights of children, the implementation of the obligations and responsibilities of parents, families, communities, governments, regional and state governments (in this study Semarang Military Court II-10 is as a government and/or country) to provide protection to children. 
The form of legal protection for victims of criminal intercourse in the judicial process is the granting of a set of rights that can be exploited by victims, in their position being processed by the court and justice and welfare must be fought together as one form of appreciation for the contribution of victims in the process. Fighting for the interests of children is closely related to issues of norms and rights relating to the condition of the child/victim concerned. (Melton-Fant, 2019)

The parties concerned with the decision number: 62-K/PM II-10/AD/IX/2016 are:

1) The party convicted is the perpetrator who is a member of the military.

2) The party that punishes or has the authority of the government/state through a court of law.

3) The victim is the child.

4) Community members (Individuals / Groups) who want punishment for their interests, for self-satisfaction and perhaps also for the sake of public order.

5) The prosecution (in a Military Oditur criminal represents the victim)

6) Defenders/accused/convicted lawyers/lawyers/ legal advisors and other beneficial members of the community.

Legal protection is protection seen from the perspective of the law or positive law in force. Legal protection from the side of law enforcement and community elements (Maul et al., 2019).

Based on the analysis in Decision Number 62-K/PM II-10/AD/IX /2016, the form of legal protection in the form of granting rights as a service to children as justice seekers granted and implemented by the Military Court II-10 Semarang, is as follows:

\section{1) Detention of the defendant before and after the trial process takes place}

The detention of the defendant before and after the trial process took place at the Court intended to facilitate the process of examination and case handling before and during the trial process (Malloy, Sutherland, \& Cauffman, 2019).

The detention was intended so that the defendant did not lose evidence and the defendant did not run away and cause trouble. The disturbance can be in the form of violence and threats that are targeted/directed at the child/victim. This detention is carried out in accordance with the rules contained in Article 79 paragraph (1) of Law No. 31 of 1997 concerning Military Justice, which is as follows:

The detention or extension of detention is carried out on suspects who are suspected of committing criminal offenses based on sufficient evidence, in the event of a situation that raises concerns that the suspect will flee, damage or eliminate evidence, or repeat the crime, or cause trouble.

Detention of the defendant during the trial process has not yet begun and during the trial, process phase is to avoid the treatment of violence against children, the detention of the defendant is intended so that the victim is not threatened by the 
defendant either social threats or threats that are physical attacks (Longobardi \& Badenes-Ribera, 2019). The physical attack in question is a threat of violence because the defendant feels unaccepted by the allegations given to him because these allegations can arouse emotions and ultimately result in violence against the child victim. With the detention of the defendant, the child as a victim will feel safe because he/she will no longer be disturbed / threatened / treated violently by the defendant / other person, so that the child's right to obtain protection from exploitation forms of violence treatment, arbitrary treatment in the criminal justice process can be fulfilled (Liu, Kong, Leslie, \& Corr, 2019).

\section{2) Provide opportunities for children (as victim-witnesses) to provide information}

In the process of examination at the Semarang Military Court II-10, at the witness examination stage in the trial, children as victims of intercourse are given the opportunity to provide information in accordance with the provisions in Law No. 35 of 2014 specifically Article 10 which stipulates that every child has the right to express and be heard, accept, seek, and provide information in accordance with the level of intelligence and age for the development of himself and the level of intelligence according to their interests and talents (Khezri, Farokhzadian, Nematollahi, Foroughameri, \& Sharifi, 2019). In this case, the victim is the party who knows the whole crime clearly. At the time of giving testimony at the trial the child was in an oath, because in Law No. 8 of 1981 concerning the Criminal Procedure Code (KUHAP) there is a regulation regarding children whose testimony is heard without an oath, which may be examined to provide information without an oath is a child whose age is not yet fifteen years old and has never been married (Article 171 letter a of the Criminal Code) (Johnson, 2019). The latest law governing children as witnesses are Law No. 11 of 2012 concerning the Child Criminal Justice System, which is in Article 1 number 5 listed as follows:

Children who become Criminal Witnesses hereinafter referred to as Witness Children, are children who are not yet 18 (eighteen) years of age who can provide information for the purposes of investigation, prosecution and examination in a court of law concerning a criminal case that is heard, seen, and/or experienced. alone.

From the explanation above we can conclude that basically, the Law on the Criminal Justice System of the Child has stipulated that the child who is a witness of a criminal offense is a child who is not yet 18 (eighteen) years old. In this case, the child was 18 years old at the time the trial process took place, so the child could be sworn in to provide information as a witness to the victim (Jackson, Chilton, Johnson, \& Vaughn, 2019). 
The assistance of children by parents/guardians, in this case, people who have a close relationship/family with the victim. Mentally the child will feel more confident if together with people who are known and closest who would have understood the situation and needs of the child when compared with people who are military figures in the trial. Children are more socially confident if in the trial process accompanied by the mother, or the parents. And in this case, the child provides information accompanied by the mother, so that it is a form of fulfillment of the implementation of protection by the family as stated in Article 20 of Law No. 35 of 2014 concerning Child Protection (Guha, Luebbers, Papalia, \& Ogloff, 2019).

\section{3) Health services with the results of Visum et Repertum as one of the judges' considerations}

Health services with the results of Visum et Repertum. The results of Visum et Repertum (VeR) as one of the judges' considerations indicate that Visum et Repertum Number 02/Ver/III/2016 has explained after a physical examination, the results on the genital part: Hymen Un Intake (Rupture) with the conclusion of the examination obtained Hymen Un Intake J.1.4.10 (The hymen is torn at 1,410 hours), proving that the victim has had sex like a husband and wife. The results of Visum et Repertum Number 02 / Ver / III / 2016 are part of the results of the examination of doctors/health teams or health services from TL IV Hospital 04.07.03 Salatiga signed by dr. Nurul Fajri. Results of the post mortem include a form of health service because it refers to Article 8 of Law No. 35 of 2014 concerning Child Protection which stipulates that children are entitled to health services or services in the health sector (Graham, Macy, Eckhardt, Rizo, \& Jordan, 2019).

\section{4) Convict the defendant with imprisonment and fines and dismissal from military service}

Although the imprisonment imposed on the convicted person has been above the minimum, the Panel of Judges sentenced the imprisonment of 3 (three) years to 6 (months) was at a minimum limit (Gonzalez-Pons, Gezinski, Morzenti, Hendrix, \& Graves, 2019). The Panel of Judges should have imprisoned for more than 3 (three) years for 6 (six) months, even exceeding the demands of the Military Oditur who demanded 4 (four) years in view of the provisions of Article 81 paragraph (1) of Law No. 23 of 2002 concerning Child Protection in which the provisions of the Article are a minimum of 3 (three) years of imprisonment and a maximum of 15 (fifteen) years imprisonment. In this case, the judge is very inappropriate in imposing a crime below the minimum, because it is seen in terms of victims who are still in the category of children (minors) and also seen from Law No. 35 of 2014 that concerning the threat of a heavier imprisonment namely a minimum imprisonment of 5 (five) years and a maximum of 15 (fifteen) years and a maximum fine of Rp. 5,000,000,000.00 (five billion rupiah). Although this crime was committed when Law No. 35 of 2014 not yet in force, the Panel of Judges should have incarcerated the prison sentence of more than 
4 (four) years and greater fines above Rp. 60,000,000.00 (sixty million), considering that the victim is still a minor, causing disgrace that will be borne by the victim during his life and very detrimental to the victim's future.

\section{ANALYZING JUDGES' CONSIDERATIONS REGARDING THE CONVICTION OF THE PERPETRATORS OF THE CRIME OF SEXUAL INTERCOURSE WITH CHILDREN COMMITTED BY MEMBERS OF THE TNI (CASE STUDY OF THE DECISION OF MILITARY COURT II-10 SEMARANG NUMBER 62-K/PM.II- 10/AD/IX/2016)}

\section{A. Juridical Considerations}

Juridical considerations are judges' considerations that are based on juridical facts revealed in the trial and by the fact law including the indictments and statements of witnesses, evidence, articles in the criminal law regulations and so on (Gartland, Giallo, Woolhouse, Mensah, \& Brown, 2019).

\section{1) Military Oditur Indictment}

In this case, the Panel of Judges chose the first alternative indictment, namely Article 81 paragraph (2) of Law No. 23 of 2002 concerning Child Protection. In the Indictment in the form of alternatives, the charges are several offenses, but in fact, the indictment is intended, and which must be proven only one criminal offense. So it is up to the Military Oditur which actions are judged to have been successfully proven before the court without being related to the order of the criminal acts charged (Fortin-Langelier et al., 2019). Often occurs Military prosecutors get a criminal case that is difficult to determine one of the articles between 2-3 articles that are interrelated elements because not criminal is an element that raises doubts for military prosecutors to determine between 2 or more articles of a criminal offense.

In this study, the criminal offense charged by the Military Oditur is the first indictment of article 81 paragraph (2) of Law Number 23 the of 2002 concerning Child Protection or the second indictment of article 281 paragraph (1) of the Criminal Code.

\section{2) Witness'Statement}

Witness (victim) namely Witness-1, Witness-2 as the adoptive mother, Witness- 3 as the victim's biological mother, Witness-4 as the defendant's wife, witnesses have provided information in accordance with what was given to the investigator and the information has been contained in the news the proceedings in which the statements, in essence, have supported the indictment of the public prosecutor and justified the defendant's actions (Eisenbruch, 2019). 


\section{3) Defendant's Statement}

In the trial, the defendant had given a statement which in principle had acknowledged the intercourse committed against witness-l (the victim), but the defendant also gave a denial of the witness-1 statement, (Diegmann, 2019) the things the defendant denied were as follows:

a. The defendant did not see any blood coming out from the vagina of the witness-1 when he first had intercourse on November 17, 2012

b. The defendant was never notified by witness-l if witness-1 had been pregnant and the defendant also never gave drugs to abort the contents of witness-1

c. The defendant not only gave money once to witness-1 but more or less every three days he always gave money to witness-1

d. The defendant never put a gun-type firearm on witness-1

In this case, witness-l is a victim, namely a party who is fully aware of the crime. At the time of giving testimony at the trial witness-1 was already in an oath, because in Law No. 8 of 1981 concerning the Criminal Procedure Code (KUHAP) there is a regulation regarding children whose testimony is heard without an oath, which may be examined to provide information without an oath is a child whose age is not yet fifteen years old and has never been married (Article 171 letter a of the Criminal Code). The latest law governing children as witnesses are Law No. 11 of 2012 concerning the Child Criminal Justice System, which is in Article 1 number 5 listed as follows:

Children who become Criminal Witnesses hereinafter referred to as Witness Children, are children who are not yet 18 (eighteen) years of age who can provide information for the purposes of investigation, prosecution and examination in a court of law concerning a criminal case that is heard, seen, and/or experienced alone (Boisjoli, Hébert, Gauthier-Duchesne, \& Caron, 2019).

From the explanation above we can conclude that basically, the Law on the Criminal Justice System of the Child has stipulated that the child who is a witness of a criminal offense is a child who is not yet 18 (eighteen) years old. In this case, witness $l$ as a child who was 18 years old at the time of the trial process took place, so witness $l$ can be sworn in to provide information as a victim-witness.

\section{4) Expert Statement}

The results of Visum et Repertum (VeR) as one of the judges' considerations are the results of the examination process carried out by doctors that are basically related to the health sector. It is the duty of a doctor or an expert doctor to help law enforcement officials in handling criminal cases (Blom \& Knudson, 2019). Based on the decision, the results of Visum et Repertum (VeR) as one of the judges' considerations indicate that Visum et Repertum Number 02/Ver/III/2016 has been explained after physical examination, the results are on the sex: Hymen Un Intake (Rupture) with the conclusion of the examination obtained Hymen Un Intake J.1.4.10 (The hymen 
was torn at 1.4.10 hours), proving that the victim had had sex like a husband and wife. The results of Visum et Repertum Number 02/Ver/III/2016 are part of the results of the examination of doctors/health teams or health services from TL IV Hospital 04.07.03 Salatiga signed by dr. Nurul Fajri. Results of the post mortem include a form of health service because it refers to Article 8 of Law No. 35 of 2014 concerning Child Protection which stipulates that children are entitled to health services or services in the health sector (Barlow et al., 2019).

\section{5) Evidence}

Evidence, in this case, is in the form of the following documents:

a. 1 (one) photocopy of Birth Certificate No. 559/1997 on behalf of Witness-1.

b. 1 (one) copy of Family Card Number: $337301010105000 B$ in the name of the biological father of witness- 1 .

c. 1 (one) photocopy of STTB SMP in the name of Witness-1.

d. 1 (one) photocopy of a copy of Marriage Certificate Quotation Book Number: 019/19/I/2004 dated January 6, 2004, issued by KUA Sidorejo Kec. Sidorejo Kodya Salatiga.

e. 4 (four) copies of Visum Et Repertum copy from Kindergarten IV IV 04.07.03 number: 02/Ver/III/2016 dated 31 March 2016 on behalf of Witness-1.

f. 3 (three) copies of the guest list staying at the Slamet Hotel / Wisma Jalan Jend Sukowati Kodya Salatiga.

g. 8 (three) pieces of photos of the hotel used by the Defendant and Witness 1 committed sexual intercourse, namely Giri Mas Kopeng Hotel Kec. Bandungan Kab. Semarang, Lavande Hotel, Slamet Hotel Palapa Jetis Salatiga Hotel.

h. 1 (one) photo sheet of the defendant with witness-1 (victim).

Based on Law No. 35 of 2014 Article 1 paragraph (1) A child is someone, who is not yet 18 (eighteen) years old, including children who are still in the womb. The age of 18 here is the beginning of the age of maturity. And the age of the child starts from the age of 1 day even while still in the womb until the age of 18 years. Whereas in Law No. 4 of 1979 article l paragraph (2) explained about the understanding of children is a person who has not reached the age of 21 years or has never been married. This 21 -year limit is applied because of consideration of the interests of social enterprises, the stage of social maturity, personal maturity and mental maturity of a child reached at the age of 21 years. And in Article 45 of the Criminal Code, it is explained that children are people who are not old enough, with not yet old enough to mean those who commit acts before the age of 16 years.

Indecision number 62-K/PM.II-10/AD/IX/2016 one of the judges' considerations is as follows:

Considering whereas evidence of letter 1 (one) copy of Birth Certificate No. 559/1997 dated May 26, 1997 on behalf of Witness 1, 1 (one) copy of the Salatiga Middle School 9 Middle School Academic Year 2012/2013 Academic Year on June 1, 2013 on behalf of Witness 1 and 1 (one) photocopy of Family Card No.: 
3373010101050008 issued by the Sidorejo District, Salatiga City, Central Java Province on behalf of Br. Wartono, has been shown to Defendant, Witness-1, Witness-2 and Witness- 3 and all of them confirmed, all of the evidence shows that Witness-1 was born on May 13, 1997, and then connected with the first act of intercourse committed by the Defendant and Witness -1, conducted on November 17, 2012, where Witness-1 was still in grade 3 at SMP Negeri 9 Salatiga, exactly 15 years and 6 months, therefore the evidence could be used to strengthen the evidence in this case.

The Convention on the Rights of the Child (CRC) limits children under 18 to eighteen years. Psychologically, children aged 17 years are still unstable so that the age limit in CRC is considered appropriate. So with the change of age restrictions in the law in Indonesia has also been adjusted to the maturity of a person's psychology. (Asadi-Pooya et al., 2019) If it was considered that the age of 15 years was ripe, then it is not today. So that the age limit of children past and present in the Act is different. This refers to existing laws. In addition, children also cannot do legal actions. Although in law No. 35 of 2014 children are only limited by age, ie less than 18 years.

In the ruling the evidence in the form of a photocopy of the Birth Certificate Quotation, a photocopy of the Junior High School diploma and a photocopy of the Family Card shows that the child as a victim-witness has been aged 15 years 6 months so that it is right to be called a child (under age).

\section{6) Other articles in the Child Protection Act as the Basis for Criminal Justice}

Article 81 of Law Number 23 of 2002 concerning Child Protection which was originally as follows:

(1) Any person who intentionally acts violently or threatens to force a child to have intercourse with him or with another person shall be liable to a maximum imprisonment of 15 (fifteen) years and a minimum of 3 (three) years and a maximum fine of Rp. 300,000,000.00 (three hundred million rupiahs).

(2) The criminal provisions referred to in paragraph (1) shall also apply to anyone who deliberately deceives. A series of lies, or persuading children to have intercourse with her or with others.

It has been updated with Law No. 35 of 2014 concerning Child Protection, in which the length and weight of the fine has been amended as follows:

(1) Every person who violates the provisions referred to in Article 76D shall be sentenced to a maximum imprisonment of 5 (five) years and a maximum of 15 (fifteen) years and a maximum fine of $\mathrm{Rp}$. $5,000,000,000.00$ (five billion rupiah). 
(2) The criminal provisions referred to in paragraph (1) shall also apply to any person who intentionally commits tricks, a series of lies or entices the Child to have intercourse with him or with another person.

Article 81 in Law Number 35 of 2014 clearly the amount of criminal punishment is heavier than Article 81 paragraph (2) of Law Number 23 of 2002 concerning Child Protection.

\section{B. Non-Juridical Considerations}

Non-Juridical considerations are the background of the crime, the consequences, the condition of the defendant, the socio-economic and environmental conditions of the defendant's family, and religious factors (Andersen, 2019).

In addition to understanding this background, in imposing a crime against a criminal offense, the judge can also use several theories of making criminal decisions, one of which is the balance theory, what is meant in this balance theory is the balance between the conditions determined by the Act and the interests of the party concerned or related to the case, that is, such as a balance relating to the interests of the community, the interests of the accused, and the interests of the victim (Alizadehgoradel, Imani, Nejati, \& Fathabadi, 2019). In criminal justice practices, the balance between the interests of the community and the interests of the defendant is formulated in consideration of matters that will incriminate and mitigate criminal conviction for the defendant where the interests of the community are formulated in aggravating matters, then the interests of the accused are formulated in mitigating matters. This consideration is a factor that determines the severity of the sentence imposed on the defendant (Manay \& Collin-Vézina, 2019).

The interests of the community and the interests of the victim in this matter will be formulated in Matters which incriminate the defendant's criminal, as follows:

a. The defendant has been convicted in the case of Disease

b. The defendant was sentenced to a 14-day disciplinary sentence for marrying a sister to the Witness-4 sister who is now his wife before the Defendant divorced his first wife.

c. The Defendant's actions damaged the image of the TNI especially the Salatiga Military Police Detachment IV/3 Unit especially in the Kelorea Sidorejo Lor community, Sidorejo District, Salatiga District.

d. The Defendant's actions have damaged the victim's future by snatching the victim's virginity and running away from his responsibility.

e. The Defendant's actions have caused a disgrace to the victim's family in their neighborhood.

f. The Defendant's actions are very contrary to TNI's doctrine where each soldier must uphold discipline, uphold the attitude and honor of the soldier wherever the Defendant is, subject to the law and uphold the honor of women as referred to in the Sapta Marga, Oath of Warriors and Eight Mandatory TNI. 
Then the Defendant's own interests will be formulated in Matters which relieve the defendant's criminal offenses, as follows:

a. The defendant was cooperative, forthright in providing information so as to smooth the proceedings.

b. The defendant pleaded guilty to his actions.

\section{CONCLUSION}

Based on the results of research and discussion, it can be concluded several things including, Implementation of Law Number 35 the Year 2014 Regarding Protection of Children against the crime of sexual intercourse against children committed by members of the TNI in the judicial process at the Military Court II-10 Semarang consists of:

a. The detention of the defendant before and after the trial process took place. With the detention of the defendant, it is intended that the defendant does not eliminate evidence and to avoid the treatment of violence against victims so that the right of children to obtain protection from forms of exploitation of violence treatment can be fulfilled.

b. Provide opportunities for children (as victim-witnesses) to provide information before the court. This is the child's right to provide information about himself as referred to in Article 10 of Law No. 35 of 2014 concerning Child Protection.

c. Health services with the results of Visum et Repertum. VeT results are the results of experts in the health sector obtained by children as a form of fulfilling health services as regulated in Article 8 of Law No. 35 of 2014 concerning Child Protection.

Then the Judge's Consideration regarding the conviction of the perpetrators of the crime of sexual intercourse with children committed by members of the TNI in the Decision of Military Court II-10 Semarang Number 62-K/PM.II-10/AD/IX 2016 consisting of:

1) Juridical Considerations

a. The first alternative indictment is Article 81 paragraph (2) of Law No. 23 of 2002 concerning Child Protection

b. The statements of the accused, witnesses and expert statements regarding the Visum Et Repertum are among the judges' considerations

c. Evidence in the form of a photocopy of a birth certificate, diploma, and family card strengthens the evidence that the child is not yet 18 years old or is underage

d. Articles in the Child Protection Act as the Basis for Criminal Conduct

2) Non-Juridical Considerations

Non-Juridical considerations are the background of the crime, the consequences, the condition of the defendant, the socio-economic and environmental conditions of the defendant's family, and religious factors. As well as considering things that lighten and incriminate the defendant's criminal. 


\section{REFERENCES}

Alizadehgoradel, J., Imani, S., Nejati, V., \& Fathabadi, J. (2019). Mindfulness-based substance abuse treatment (MBSAT) improves executive functions in adolescents with substance use disorders. Neurology, Psychiatry and Brain Research, 34(July), 13-21. https://doi.org/10.1016/j.npbr.2019.08.002

Andersen, S. L. (2019). Stress, sensitive periods, and substance abuse. Neurobiology of Stress, 10, 100140. https://doi.org/10.1016/j.ynstr.2018.100140

Asadi-Pooya, A. A., Myers, L., Valente, K., Restrepo, A. D., D’Alessio, L., Sawchuk, T., Homayoun, M., Bahrami, Z., Alessi, R., Paytan, A.A., Kochen, S., Buchhalter, J., Taha, F., Lazar, L.M., Pick, S., Nicholson, T. (2019). Sex differences in demographic and clinical characteristics of psychogenic nonepileptic seizures: A retrospective multicenter international study. Epilepsy and Behavior, 97, 154-157. https://doi.org/10.1016/j.yebeh.2019.05.045

Barlow, J., Sembi, S., Parsons, H., Kim, S., Petrou, S., Harnett, P., \& Dawe, S. (2019). A randomized controlled trial and economic evaluation of the Parents Under Pressure program for parents in substance abuse treatment. Drug and Alcohol Dependence, 194, 184-194. https://doi.org/10.1016/j.drugalcdep.2018.08.044

Blom, D. E., \& Knudson, K. J. (2019). Paleopathology and children in the Andes: Local/situated biologies and future directions. International Journal of Paleopathology, (February), l-1l. https://doi.org/10.1016/j.ijpp.2019.08.004

Boisjoli, C., Hébert, M., Gauthier-Duchesne, A., \& Caron, P. O. (2019). A mediational model linking perceptions of security, alexithymia and behavior problems of sexually abused children. Child Abuse and Neglect, 92(November 2017), 66-76. https://doi.org/10.1016/j.chiabu.2019.03.017

Diegmann, A. (2019). The internet effects on sex crime offenses - Evidence from the German broadband internet expansion. Journal of Economic Behavior \& Organization, 165, 82-99. https://doi.org/10.1016/j.jebo.2019.07.001

Eisenbruch, M. (2019). "His body is human, but he has a tiracchāna heart": An ethnographic study of the epigenesis of child abuse in Cambodia. Child Abuse and Neglect, 88(September 2018), 129-143. https://doi.org/10.1016/j.chiabu.2018.10.018

Fortin-Langelier, E., Daigneault, I., Achim, J., Vézina-Gagnon, P., Guérin, V., \& Frappier, J. Y. (2019). A Matched Cohort Study of the Association Between Childhood Sexual Abuse and Teenage Pregnancy. Journal of Adolescent Health, 65(3), 384-389. https://doi.org/10.1016/j.jadohealth.2019.03.001

Gartland, D., Giallo, R., Woolhouse, H., Mensah, F., \& Brown, S. J. (2019). Intergenerational Impacts of Family Violence - Mothers and Children in a Large Prospective Pregnancy Cohort Study. EClinicalMedicine, (xxxx). https://doi.org/10.1016/j.eclinm.2019.08.008

Gonzalez-Pons, K. M., Gezinski, L., Morzenti, H., Hendrix, E., \& Graves, S. (2019).

Exploring the relationship between domestic minor sex trafficking myths, victim 
identification, and service provision. Child Abuse \& Neglect, (February), 104093. https://doi.org/10.1016/j.chiabu.2019.104093

Graham, L. M., Macy, R. J., Eckhardt, A., Rizo, C. F., \& Jordan, B. L. (2019). Measures for evaluating sex trafficking aftercare and support services: A systematic review and resource compilation. Aggression and Violent Behavior, 47(July 2018), 117-136. https://doi.org/10.1016/j.avb.2019.04.001

Guha, A., Luebbers, S., Papalia, N., \& Ogloff, J. R. P. (2019). A follow-up study of mental health service utilisation in a cohort of 2433 sexually abused Australian children utilising five years of medical data. Child Abuse and Neglect, 90(August 2018), 174-184. https://doi.org/10.1016/j.chiabu.2019.01.015

Jackson, D. B., Chilton, M., Johnson, K. R., \& Vaughn, M. G. (2019). Adverse Childhood Experiences and Household Food Insecurity: Findings From the 2016 National Survey of Children's Health. American Journal of Preventive Medicine, 57(5), 667-674. https://doi.org/10.1016/j.amepre.2019.06.004

Johnson, B. C. (2019). Trauma recovery for victims of sex trafficking. Child Abuse $\approx$ Neglect, (February), 104153. https://doi.org/10.1016/j.chiabu.2019.104153

Khezri, M., Farokhzadian, J., Nematollahi, M., Foroughameri, G., \& Sharifi, H. (2019). HIV/AIDS prevention education: An effective tool for enhancing street children's knowledge and attitude. A randomized controlled trial. Children and Youth Services Review, 104(June). https://doi.org/10.1016/j.childyouth.2019.05.028

Klifto, C. S., Lavery, J. A., Gold, H. T., Milone, M. T., Karia, R., Palusci, V., \& Chu, A. (2019). Journal of Hand Surgery Global Online Pediatric Fingertip Injuries: Association With Child Abuse. Journal of Hand Surgery Global Online. https://doi.org/10.1016/j.jhsg.2019.09.001

Komori, K., Komori, M., Eitoku, M., Joelle Muchanga, S. M., Ninomiya, H., Kobayashi, T., \& Suganuma, N. (2019). Verbal abuse during pregnancy increases frequency of newborn hearing screening referral: The Japan Environment and Children's Study. Child Abuse and Neglect, 90(February), 193-201. https://doi.org/10.1016/j.chiabu.2019.01.025

Liu, G., Kong, L., Leslie, D. L., \& Corr, T. E. (2019). A Longitudinal Healthcare Use Profile of Children with a History of Neonatal Abstinence Syndrome. Journal of Pediatrics, 204, 111-117.el. https://doi.org/10.1016/j.jpeds.2018.08.032

Longobardi, C., \& Badenes-Ribera, L. (2019). The relationship between animal cruelty in children and adolescent and interpersonal violence: A systematic review. Aggression and Violent Behavior, 46(July), 201-21l. https://doi.org/10.1016/j.avb.2018.09.001

Malloy, L. C., Sutherland, J. E., \& Cauffman, E. (2019). Sexual abuse disclosure among incarcerated female adolescents and young adults. Child Abuse \& Neglect, (July 2018), 104147. https://doi.org/10.1016/j.chiabu.2019.104147

Manay, N., \& Collin-Vézina, D. (2019). Recipients of children's and adolescents' disclosures of childhood sexual abuse: A systematic review. Child Abuse \& Neglect, (June 2018), 104192. https://doi.org/10.1016/j.chiabu.2019.104192

Maul, K. M., Naeem, R., Rahim Khan, U., Mian, A. I., Yousafzai, A. K., \& Brown, N. 
(2019). Child abuse in Pakistan: A qualitative study of knowledge, attitudes and practice amongst health professionals. Child Abuse and Neglect, 88(September 2018), 5l-57. https://doi.org/10.1016/j.chiabu.2018.10.008

Melton-Fant, C. (2019). Childhood adversity among Black children: The role of supportive neighborhoods. Children and Youth Services Review, 105(July), 104419. https://doi.org/10.1016/j.childyouth.2019.104419

Muhammad, H.R. (2007). Hukum Acara Pidana Kontemporer. Bandung: PT. Citra Aditya Bakti.

Panlilio, C. C., Miyamoto, S., Font, S. A., \& Schreier, H. M. C. (2019). Assessing risk of commercial sexual exploitation among children involved in the child welfare system. Child Abuse and Neglect, 87(July), 88-99. https://doi.org/10.1016/j.chiabu.2018.07.021

Ramiro, L. S., Martinez, A. B., Tan, J. R. D., Mariano, K., Miranda, G. M. J., \& Bautista, G. (2019). Online child sexual exploitation and abuse: A community diagnosis using the social norms theory. Child Abuse \& Neglect, 96(June), 104080. https://doi.org/10.1016/j.chiabu.2019.104080

Reed, S. M., Kennedy, M. A., Decker, M. R., \& Cimino, A. N. (2019). Friends, family, and boyfriends: An analysis of relationship pathways into commercial sexual exploitation. Child Abuse and Neglect, 90(October 2018), 1-12. https://doi.org/10.1016/j.chiabu.2019.01.016

Republic of Indonesia. (1946). Law Number 1 of 1946 concerning the Criminal Code Act

Republic of Indonesia. (1974). Law Number 1 of 1974 concerning Marriage

Republic of Indonesia. (1979). Law Number 4 of 1979 concerning Child Welfare

Republic of Indonesia. (1981). Law Number 8 of 1981 concerning the Criminal Procedure Code

Republic of Indonesia. (1997). Law Number 31 of 1997 concerning Military Justice

Republic of Indonesia. (1999). Law Number 39 of 1999 concerning Human Rights Republic of Indonesia. (2002). Law Number 23 of 2002 concerning Child Protection Republic of Indonesia. (2003). Law Number 13 of 2003 concerning Manpower

Republic of Indonesia. (2004). Law Number 34 of 2004 concerning the Indonesian National Army

Republic of Indonesia. (2006). Law Number 12 of 2006 concerning Citizenship of the Republic of Indonesia

Republic of Indonesia. (2007). Law Number 21 of 2007 concerning Eradication of Trafficking in Persons

Republic of Indonesia. (2008). Law Number 44 of 2008 concerning Pornography Republic of Indonesia. (2009). Law Number 22 of 2009 concerning Road Traffic and Transportation

Republic of Indonesia. (2009). Law Number 48 of 2009 concerning Basic Provisions for Judicial Power.

Republic of Indonesia. (2012). Law Number 11 of 2012 concerning the Juvenile Criminal System 
Republic of Indonesia. (1991). Compilation of Islamic Law, retrieved from https://www.basishukum.com/khi/1/1991

Republic of Indonesia. (2014). Law Number 35 of 2014 concerning Child Protection

Saito, T., Toda, H., Inoue, T., Koga, M., Tanichi, M., Takeshita, S., ... Yoshino, A. (2019). Relationship between the subtypes of child abuse and affective temperaments: Comparison of depression and bipolar disorder patients and healthy controls using the reclassified Child Abuse and Trauma Scale. Journal of Affective Disorders, 257(June), 396-403. https://doi.org/10.1016/j.jad.2019.06.043

Swiss (1937). The Swiss Criminal Code, retrieved from https://www.admin.ch/opc/en/classified-compilation/19370083/index.html

The Book of Military Criminal Law, retrieved from http://hukum.unsrat.ac.id/uu/kuhpm.htm

Verduyckt, I., Rhéault, C., Remacle, M., \& Morsomme, D. (2018). Personality Traits of Children With Vocal Fold Nodules. Journal of Voice. https://doi.org/10.1016/j.jvoice.2018.05.001

Vriesman, M. H., Bosschaart, T. V., Brilleslijper-Kater, S. N. N., Teeuw, A. H., Lindauer, R. J. L., \& Benninga, M. A. (2019). Tul606 - Prevalence of Child Abuse in Children with Functional Constipation. Gastroenterology, 156(6), S-1059-S-1060. https://doi.org/10.1016/s0016-5085(19)39611-8

Wang, L. Y., Wu, C. Y., Chang, Y. H., \& Lu, T. H. (2019). Health care utilization pattern prior to maltreatment among children under five years of age in Taiwan. Child Abuse and Neglect, 98(1), 104202. https://doi.org/10.1016/j.chiabu.2019.104202

Wahid, A., \& Irfan, M. (2001). Perlindungan Terhadap Korban Kekerasan Seksual Advokasi atas Hak Asasi Perempuan. Bandung: PT Refika Aditama.

Winstanley, E. L., \& Stover, A. N. (2019). The impact of the opioid epidemic on children and adolescents. Clinical Therapeutics, $x \times x(\mathrm{xxx}), \quad 1-8$. https://doi.org/10.1016/j.clinthera.2019.06.003

Wismayanti, Y. F., O'Leary, P., Tilbury, C., \& Tjoe, Y. (2019). Child sexual abuse in Indonesia: A systematic review of literature, law and policy. Child Abuse and Neglect, 95(June), 104034. https://doi.org/10.1016/j.chiabu.2019.104034

Wood, J. N., Henry, M. K., Berger, R. P., Lindberg, D. M., Anderst, J. D., Song, L., Localio, R., Feudtner, C. (2019). Use and Utility of Skeletal Surveys to Evaluate for Occult Fractures in Young Injured Children. Academic Pediatrics, 19(4), 428437. https://doi.org/10.1016/j.acap.2018.08.007

Woolf, S. M., Leventhal, J. M., Gaither, J. R., Hardikar, P., Langhan, M. L., Bechtel, K., Auerbach, M.A., Tiyyagura, G. (2019). Oral injuries in children less than 24 months of age in a pediatric emergency department. Child Abuse and Neglect, 89(October 2018), 70-77. https://doi.org/10.1016/j.chiabu.2019.01.006 


\section{QUOTE}

In order to escape accountability for his crimes, the perpetrator does everything in his power to promote forgetting. If secrecy fails, the perpetrator attacks the credibility of his victim. If he cannot silence her absolutely, he tries to make sure no one listens.

Judith Lewis Herman, Trauma and Recovery: The Aftermath of Violence - From Domestic Abuse to Political Terror 